\title{
Immunotoxicity evaluation of novel bioactive composites in male mice as promising orthopaedic implants
}

\author{
GEHAN T. EL-BASSYOUNI I, MARIAM G. ESHAK', IBRAHIM A.H. BARAKAT ${ }^{2,3}$, WAGDY K.B. KHALIL ${ }^{2}$ \\ ${ }^{1}$ Biomaterials Department, National Research Centre, Cairo, Egypt \\ ${ }^{2}$ Cell Biology Department, National Research Centre, Giza, Egypt \\ ${ }^{3}$ Zoology Department, College of Science, King Saud University, Riyadh, Saudi Arabia
}

\begin{abstract}
Objective: In orthopaedics, novel bioactive composites are largely needed to improve the synthetic achievement of the implants. In this work, semiconducting metal oxides such as $\mathrm{SiO}_{2}, \mathrm{TiO}_{2}$, and $\mathrm{ZrO}_{2}$ particles (Ps) were used individually and in different ratios to obtain different biphasic composites. The immunotoxicity of these composites was tested to inspect the potential toxicity prior to their use in further medical applications.

Materials and methods: In vitro mineralisation ability was inspected by soaking the composites in simulated body fluid (SBF). Additionally, in vivo experiments were performed consuming male mice using ISSR-PCR, micronucleus (MN) test, comet assay, glutathione peroxidase activity, and determination of albumin, globulin, lymphocyte population, ALT, and AST levels. Several groups of adult male albino mice were treated with 100, 200, and $400 \mathrm{mg} / \mathrm{kg}$ body weight of $\mathrm{SiO}_{2}, \mathrm{TiO}_{2}$, and $\mathrm{ZrO}_{2}-\mathrm{Ps}$ in pure or mixed forms.

Results: Our findings revealed that treatment of mice with low and medium doses of $\mathrm{SiO}_{2}, \mathrm{TiO}_{2}$, and $\mathrm{ZrO}_{2}$ Ps in pure or mixed form revealed values relatively similar to the control group. However, using 400 $\mathrm{mg} / \mathrm{kg}$ especially from $\mathrm{TiO}_{2}$-Ps in genuine form or mixed with $\mathrm{SiO}_{2}$ showed proliferation in the toxicity rates compared with the high dose of $\mathrm{SiO}_{2}$ and $\mathrm{ZrO}_{2} \mathrm{Ps}$.

Conclusions: The results suggest that $\mathrm{TiO}_{2}$ composite induced in vivo toxicity, oxidative DNA damage, bargain of the antioxidant enzymes, and variations in the levels of albumin, globulin, lymphocyte population, ALT, and AST in a dose-dependent manner. However, $\mathrm{SiO}_{2}$, and $\mathrm{ZrO}$ composites revealed a lower toxicity in mice compared with that of $\mathrm{TiO}_{2}$.
\end{abstract}

Key words: semiconducting metal oxides, ISSR-PCR, DNA damage, MN formation, glutathione peroxidase activity, A/G ratio, lymphocyte population.

(Cent Eur J Immunol 2017; 42 (1): 54-67)

\section{Introduction}

Some bioactive ceramics have already been used to repair bone defects due to their bioactivity, which allows them to achieve tight fixation resulting from direct bonding to living bone. The first bioactive ceramic developed was a glass in the $\mathrm{Na}_{2} \mathrm{O}-\mathrm{CaO}-\mathrm{SiO}_{2}-\mathrm{P}_{2} \mathrm{O}_{5}$ system, after Hench [1]. This bioactive glass was named Bioglass. Many researchers have established various types of bioactive ceramics [2-5]. They have lower fracture toughness and higher Young's modulus than that of human cortical bone [6]. Therefore, the development of novel bioactive materials with amended mechanical and biological properties, in addition to high affinity for bone tissue, was looked for.

It is important for ceramic materials to form a bonelike apatite layer on their surfaces after being exposed to the body environment, to speed their property of direct bonding to living bone. A similar bone-like apatite layer can be formed on bioactive ceramics, if they were immersed in a simulated body fluid (SBF), as proposed by Kokubo et al. SBF is an aqueous solution that has almost the same ingredients, with regard to the inorganic species, as human extracellular fluid [7-10]. Simulated body fluid does not contain any cells or proteins, which means that the apatite layer is formed through the chemical reaction of the bioactive ceramics with the surrounding fluid. It is therefore anticipated that novel bioactive materials can be produced by controlling the chemical reactivity of the materials in body fluid [11].

Based on this idea, new types of bioactive materials, such as composites of (amorphous silica) $\mathrm{SiO}_{2}$ strengthened with either (titania) $\mathrm{TiO}_{2}$ or (zirconia) $\mathrm{ZrO}_{2}$, have been developed. 
However, titania powder with high surface area are not easily obtained due to their phase transformation and crystallite growth. Therefore, efforts have been directed towards the preparation of $\mathrm{SiO}_{2} / \mathrm{TiO}_{2}$ composite microspheres in order to hinder the phase transformation [12]. Moreover, $\mathrm{SiO}_{2} / \mathrm{TiO}_{2}$ composite microspheres may exhibit novel properties that are not found in a single oxide. It was reported that $\mathrm{SiO}_{2} / \mathrm{TiO}_{2}$ composite exhibited superior catalytic properties to the classical oxides and less biocompatibility than titania and silica [13].

Titania $\left(\mathrm{TiO}_{2}\right)$, as a naturally occurring oxide, is a talented material. It possesses suitable mechanical and biocompatible properties $[14,15]$. $\mathrm{TiO}_{2}$ can initiate the formation of a strong bond to bone upon implantation via the formation of a hydroxyapatite $\left[\mathrm{Ca}_{10}\left(\mathrm{PO}_{4}\right) 6(\mathrm{OH})_{2}, \mathrm{HA}\right]$ layer [16]. Furthermore, it was found that $\mathrm{TiO}_{2}$ in $\mathrm{SiO}_{2} / \mathrm{TiO}_{2}$ composite microspheres demonstrated better photoactivity than pure $\mathrm{TiO}_{2}$ particles due to their smaller grain size and improved absorption [17].

Zirconia $\left(\mathrm{ZrO}_{2}\right)$ and titanium were used extensively in dental and orthopaedic implantation because of their mechanical properties and chemical resistance to degradation by bodily fluids. $\mathrm{ZrO}_{2}$ is tough because of its tetragonal structure; this structure can be controlled by blending it with other materials in order to balance toughness and strength. It is also one of the most extensively used ceramics in medical fields due to its good biocompatibility, excellent corrosion resistance, high strength, and low cost $[18,19]$. There is interest in using $\mathrm{ZrO}_{2}$ for biomedical applications in high load-bearing sites [20]. The biological inertness and the good biocompatibility of $\mathrm{ZrO}_{2}$ have been confirmed by many medical applications [21]. Zirconia has been commonly used in orthopaedic implant materials offering better [22] scratch resistance relative to metal and better resistance to brittle fracture than alumina $\left(\mathrm{Al}_{2} \mathrm{O}_{3}\right)$ [22-25]. In 2002, Uchida et al. found that the $\mathrm{Zr}-\mathrm{OH}$ group formed on zirconium metal after pre heat treatment in $\geq 5 \mathrm{M}$ aqueous sodium hydroxide $(\mathrm{NaOH})$ solution showed the ability to induce apatite formation in simulated body fluid SBF [26-28].

To date, there has been no published data available concerning evaluation of the in vivo toxicity of $\mathrm{SiO}_{2}, \mathrm{TiO}_{2}$, and $\mathrm{ZrO}_{2}$ composites. Therefore, the present study was planned to explore the bio-safety of novel bioactive composites of $\mathrm{SiO}_{2}$, $\mathrm{TiO}_{2}$, and $\mathrm{ZrO}_{2}$ on the immune and genetic materials of male mice before its use in further biomedical applications.

\section{Material and methods}

\section{Chemicals}

$\mathrm{TiO}_{2}$ powder (anatase form) was purchased from $\mathrm{BDH}$ (England). Silicon oxide $\left(\mathrm{SiO}_{2}\right)$, amorphous, $99.5 \%$, was purchased from Alfa Aesar (USA). Zirconia powder (Zirconium Oxide, $\mathrm{ZrO}_{2}$ ) was purchased from Zircoa (Germany). The chemicals for molecular analysis (ISSR-PCR) were bought from Invitrogen (Carlsbad, CA, USA).

\section{In vitro bioactivity test}

Results obtained from in vitro experiments cannot usually be restructured as is to expect the reaction of an entire organism in vivo. Building a reliable extrapolation procedure from in vitro results to in vivo is therefore essential. The importance of exploring in vitro bioactivity prior to in vivo is quite clear, as in vivo studies require animal sacrifices, which are more costly, less easily reproducible, and involve ethical issues. For these reasons, before in vivo, screenings being carried out in in vitro tests are necessary. The scientific community hypothesised that SBF can be used to assess the in vitro bioactivity of a material. Simulated body fluid is an aprotic and acellular solution that has an inorganic ion concentration similar to that of human extracellular fluid, to mimic the formation of apatite on bioactive materials in vitro.

To study the bioactivity, samples were soaked in $50 \mathrm{ml}$ of simulated body fluid (SBF) with ion concentrations $\left(\mathrm{Na}^{+}\right.$ 142.0, $\mathrm{K}^{+}$5.0, $\mathrm{Mg}^{2+} 1.5, \mathrm{Ca}^{2+}$ 2.5, $\mathrm{Cl}^{-}$147.8, $\mathrm{HCO}_{3}^{-}$4.2, $\mathrm{HPO}_{4}{ }^{2-} 1.0, \mathrm{SO}_{4}{ }^{2-} 0.5 \mathrm{Mm}$ ) nearly equal to those of human blood plasma at $36.5^{\circ} \mathrm{C}$. Simulated body fluid (prepared following Kokubo's protocol) [7, 8]. Simulated body fluid was prepared by dissolving reagent grade chemicals one by one in the order $\mathrm{NaCl}, \mathrm{NaHCO}_{3}, \mathrm{KCl}, \mathrm{K}_{2} \mathrm{HPO}_{4} \cdot 3 \mathrm{H}_{2} \mathrm{O}, \mathrm{MgCl}_{2} \cdot 6 \mathrm{H}_{2} \mathrm{O}$, $\mathrm{CaCl}_{2}$, and $\mathrm{Na}_{2} \mathrm{SO}_{4}$ into double-distilled water, and buffered at $\mathrm{pH} 7.40$ with tris(hydroxymethyl)aminomethane $\left[\left(\mathrm{CH}_{2} \mathrm{OH}\right)\right.$ $\left.\mathrm{CNH}_{3}\right]$ and approximately $45 \mathrm{mM}$ of hydrochloric acid $(\mathrm{HCl})$ at $36.5^{\circ} \mathrm{C}$. After soaking for 15 days, samples were withdrawn from the SBF solution, gently washed with distilled water, dried in air, and kept in an incubator to assess their acellular bioactivity $[29,30]$.

To estimate the formation of hydroxycarbonate apatite (HCA) aggregates on the surface of materials post immersion, samples were characterised via scanning electron microscopy (SEM, JEOL JXA-840, Tokyo, Japan, Electron Probe Microanalyzer).

\section{In vivo study}

Experimental animals: The animal experiments were conducted at the animal house facility, affiliated to the National Research Centre (NRC). The study in vivo protocol was approved by the Institutional Animal Ethics Committee of the NRC. Two hundred and ninety adult male albino mice (20-25 g, purchased from the Animal House Colony, Giza, Egypt) were maintained on standard laboratory diet (protein, 16.04\%; fat, 3.63\%; fibre, $4.1 \%$; and metabolic energy, $0.012 \mathrm{~mJ}$ ) and water ad libitum. After an acclimation period of one week, animals were estranged into several groups (10 mice/group) and housed individually in filter-top polycarbonate cages housed in a temperature-controlled $\left(23 \pm 1^{\circ} \mathrm{C}\right)$ and artificially illuminated (12-hour dark/light cycle) room free from any source of chemical detoxification.

Experimental design: According to Najda et al. [31], three doses of unmixed and mixed materials of $\mathrm{SiO}_{2}, \mathrm{TiO}_{2}$, 
and $\mathrm{ZrO}_{2}$-particles (Ps): 100, 200, and $400 \mathrm{mg} / \mathrm{kg}$ were used for the evaluation of toxicity. The in vivo experiments were performed on negative control (untreated mice), positive control (cyclophosphamide), and the experimental groups including unmixed and mixed materials of $\mathrm{SiO}_{2}$, $\mathrm{TiO}_{2}$, and $\mathrm{ZrO}_{2}$. The experimental groups were divided into three unmixed subgroups $\left(\mathrm{SiO}_{2}, \mathrm{TiO}_{2}\right.$, and $\mathrm{ZrO}_{2}$, respectively) and six mixed subgroups $\left(\mathrm{SiO}_{2} / \mathrm{TiO}_{2}: 1: 1\right.$, $1: 2$, and $1: 3 ; \mathrm{SiO}_{2} / \mathrm{ZrO}_{2}: 1: 1,1: 2$, and $1: 3$, respectively). All groups had corresponding numbers of animals per test in which for Inter Simple Sequence Repeats (ISSR), bone marrow micronucleus (MN), and enzyme activity assays, for each dose 10 animals were used. All animals were given an IP single dose once per week for one month. The control group was treated with saline water. A known mutagen, cyclophosphamide, at a dose of $40 \mathrm{mg} / \mathrm{kg}$ body weight (bw) was used for the positive control group. It was given intraperitoneally (i.p.), and the volume injected was $0.01 \mathrm{ml} / \mathrm{g}$ b.w. Samples of liver were immediately kept on ice and frozen at $-20^{\circ} \mathrm{C}$ prior to usage for ISSR-PCR and enzyme activity analyses. Bone marrow samples were collected from both femurs of each animal and extracted immediately and processed for the MN assay.

Extraction of genomic DNA: Total genomic DNA was isolated from mice liver tissue samples $(100 \mathrm{mg})$ by cutting first into very fine pieces and digesting at $37^{\circ} \mathrm{C}$ overnight in TNES-Urea solution (10 mM Tris- $\mathrm{HCl}, 125 \mathrm{mM} \mathrm{NaCl}$, $10 \mathrm{mM}$ EDTA 2Na, 1\% SDS, and $8 \mathrm{M}$ Urea) with $10 \mathrm{mg}$ / $\mathrm{ml}$ proteinase $\mathrm{K}$, as described by Asahida et al. [32]. DNA was extracted from each sample following the standard procedure of SDS-phenol chloroform. Subsequently, DNA was precipitated in cold ethanol, re-suspended in TE buffer, and stored at $4^{\circ} \mathrm{C}$ until PCR amplification. The concentration of genomic DNA samples was determined via UV spectrometer and necessary dilutions were done, followed by verification with $0.8 \%$ agarose gel electrophoresis.

ISSR-PCR and electrophoresis: Inter Simple Sequence Repeat (ISSR) analysis was performed using the six different primers listed in Table 1. The primers contained different diand tri-nucleotide repeat motifs in order to achieve as wide as possible genome coverage. For each primer, the annealing temperature was chosen after different trials with different

Table 1. ISSR primer codes, sequences, and their annealing temperature used for ISSR-PCR

\begin{tabular}{cccc}
\hline $\begin{array}{c}\text { Primer } \\
\text { set }\end{array}$ & Primer Code & $\begin{array}{c}\text { Primer sequence } \\
\left(\mathbf{5}^{\prime}-\mathbf{3}^{\prime}\right)\end{array}$ & $\begin{array}{c}\text { Annealing T } \\
\left({ }^{\circ} \mathbf{C}\right)\end{array}$ \\
\hline 1 & HB8 & $(\mathrm{GA}) 6 \mathrm{GG}$ & 48 \\
\hline 2 & HB9 & $(\mathrm{GT}) 6 \mathrm{GG}$ & 48 \\
\hline 3 & HB10 & (GA) 6 CC & 48 \\
\hline 4 & HB11 & (GT) 6 CC & 48 \\
\hline 5 & HB15 & (GTG) $3 \mathrm{GC}$ & 52 \\
\hline 6 & 814 & (CT) $8 \mathrm{TG}$ & 44 \\
\hline
\end{tabular}

temperatures (tested range from $48-52^{\circ} \mathrm{C}$ ), aiming to maximise the information obtained from the patterns, i.e. maximum amplification, minimum smear on gels (from non-specific amplification), and well-resolved bands.

The PCR solution ( $25 \mu$ l total volumes) contained 0.5 units of Taq DNA Polymerase (Pharmacia $\left.{ }^{\circledR}\right), 1 \times$ reaction buffer, $2.5 \mathrm{mM} \mathrm{MgCl}, 0.2 \mu \mathrm{M}$ primer, $200 \mu \mathrm{M}$ of each $\mathrm{dNTP}$, and up to $30 \mathrm{ng}$ of genomic DNA. PCR amplifications were performed using the following conditions: $94^{\circ} \mathrm{C}$ for two minutes; 35 cycles of: $94^{\circ} \mathrm{C}$ for 30 seconds, $44^{\circ} \mathrm{C}$ for 45 seconds, $72^{\circ} \mathrm{C}$ for 1 minute 30 seconds; $72^{\circ} \mathrm{C}$ for 20 minutes; and $4^{\circ} \mathrm{C}$ soak forever. In order to exclude PCR artefacts and verify the repeatability of the results, negative controls and replicates were included in each PCR amplification. For ISSR marker profiling, PCR products were subjected to electrophoresis on $1.5 \%$ agarose gels, followed by staining using ethidium bromide [an intercalating agent commonly used as a fluorescent tag (nucleic acid stain) in molecular biology]. The electrophoretic patterns of the PCR products were digitally recorded using a Gel-Doc 2000 image analysis system (Bio-Rad) according to the instruction of the manufactory.

Micronucleus test: Acridine orange [an organic compound used as a nucleic acid-selective fluorescent cationic dye useful for cell cycle determination - being cell-permeable, it interacts with DNA and RNA by intercalation or electrostatic attractions respectively] staining of erythrocytes was performed using a procedure used by Ueda $e t$ al. [33]. To assess this assay, five animals from each treatment were sacrificed after the exposure period. The bone marrow cells were collected from both femurs and re-suspended in a small volume of foetal calf serum (FBS; Sigma) on a $0.003 \%$ acridine orange-coated glass slide. The slide was then covered with a cover glass to prepare bone marrow specimens. Slides were dried overnight and fixed with methanol for 10 minutes. Bone marrow specimens were examined in a blinded manner using fluorescence microscopy at $600 \times$ or higher magnification with a blue excitation wavelength (e.g. $488 \mathrm{~nm}$ ) and yellow-to-orange barrier filter (e.g. $515 \mathrm{~nm}$ long pass). Two slides per animal were observed once by a single observer who had sufficient experience of micronucleus test. The number of micronucleated polychromatic erythrocytes (\%MnPCEs) was measured at a rate of 3000 polychromatic erythrocytes (PCEs) per animal.

Comet assay for DNA strand break determination: Mice hepatic tissues of all groups were subjected to modified single-cell gel electrophoresis [34]. In order to obtain the cells, a small piece of the liver was first thoroughly washed using an excess amount of ice-cold Hank's balanced salt solution (HBSS) and then minced quickly, using a pair of stainless steel scissors, to form approximately $1-\mathrm{mm}^{3}$ pieces, while immersed in HBSS. After several washings with cold phosphate-buffered saline to get rid of red blood cells (RBCs), the minced liver was dispersed individually into single cells using a pipette. In brief, the 
protocol for electrophoresis involved embedding the isolated cells in agarose gel on microscopic slides, lysing them with detergent at high salt concentrations (overnight in the cold), treatment with alkali to denature the DNA (20 minutes), and electrophoresis under alkaline conditions (30 minutes) at $300 \mathrm{~mA}, 25 \mathrm{~V}$. After electrophoresis the slides were stained by means of ethidium bromide and examined using a fluorescence microscope (Olympus BX60 F-3) with a green filter at $\times 40$ magnification. For each experimental condition, about 100 cells (about 25 cells per fish) were examined to determine the percentage of cells with DNA damage, which appear as comet-like shapes. Randomly selected non-overlapping cells were visually assigned a score on an arbitrary scale of $0-3$ (i.e. class $0=$ no detectable DNA damage and no tail; class $1=$ tail with a length less than the diameter of the nucleus; class $2=$ tail of length between $1 \times$ and $2 \times$ the nuclear diameter; and class $3=$ tail longer than $2 \times$ the diameter of the nucleus), based on apparent comet tail length migration and relative proportion of DNA in the nucleus [35]. A total damage score for each slide was derived by multiplying the number of cells assigned to each class of damage by the numeric value of the class and summing up all the values. Slides were analysed by one observer to minimise the scoring variability.

Determination of glutathione peroxidase activity: Glutathione peroxidase activity measurements were carried out by a procedure according to El-Megeed et al. [36]. The reaction mixture consisted of $8 \mathrm{mM} \mathrm{H}_{2} \mathrm{O}_{2}, 40$ $\mathrm{mM}$ guaiacol, $50 \mathrm{mM}$ sodium acetate buffer $\mathrm{pH} 5.5$, and a suitable amount of the enzyme preparation. Change in absorbance at $470 \mathrm{~nm}$ due to guaiacol oxidation was followed at 30-second intervals. One unit of glutathione peroxidase activity was defined as the amount of enzyme that increases the O.D. 1.0/min under standard assay conditions.

Determination of albumin and globulin as well as A/G ratio levels: Serum albumin and globulin were assessed according to manufacturer instructions of commercially available test kits.

Analysis of lymphocyte population in blood: Lymphocyte population distribution in peripheral blood of male mice in different treated groups was examined using flow cytometry method [37].

Determination of aspartate aminotransferase (AST) and alanine aminotransferase (ALT): AST and ALT activities were measured using kits of QCA, Spain, according to the method of Rasmy et al. [38]. AST and ALT activities were expressed as U/l.

\section{Statistical analysis}

All data were analysed using the General Liner Models (GLM) procedure of the Statistical Analysis System [39], followed by Scheffé-test to assess significant differences between groups. The values are expressed as mean \pm SEM. All statements of significance were based on a probability of $p<0.05$.

\section{Results}

\section{Surface morphology}

The water molecules found in the SBF instantaneously react with the $\mathrm{Si}-\mathrm{O}-\mathrm{Si}$ or $\mathrm{Ti}-\mathrm{O}-\mathrm{Ti}$ bond to form additional $\mathrm{Si}-\mathrm{OH}$ or $\mathrm{Ti}-\mathrm{OH}$ groups. These formed groups induce the nucleation of apatite, as well as the discharge of both the $\mathrm{Ca}^{2+}$ and $\mathrm{Na}^{+}$ions from the SBF solution, which may

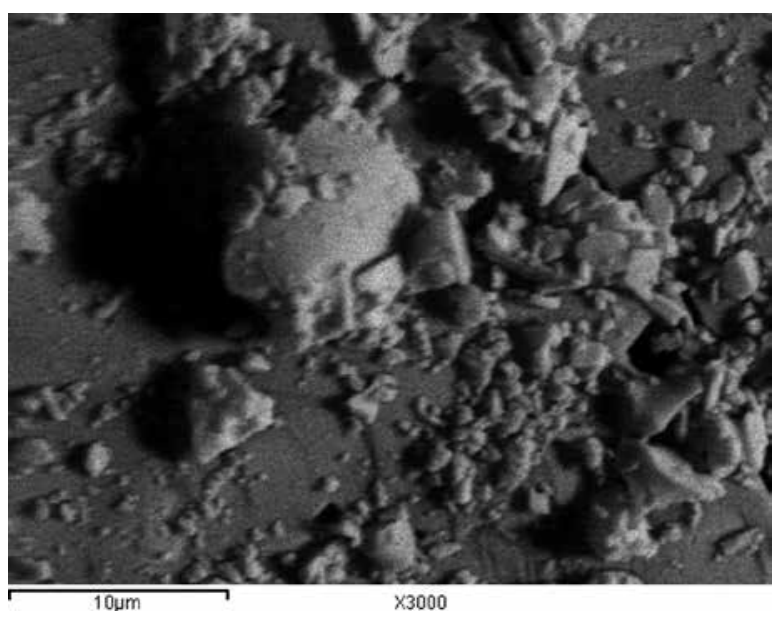

Fig. 1. SEM micrograph of pure $\mathrm{SiO}_{2}$ represents different agglomerates precipitated on top of the sample after immersion for two weeks

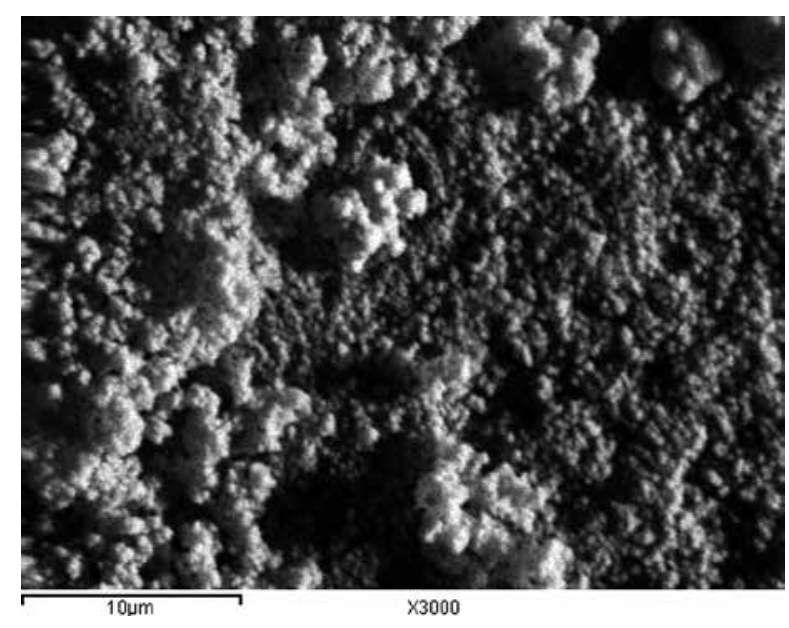

Fig. 2. SEM micrograph shows pure $\mathrm{TiO}_{2}$ with few agglomerates. The image of pure $\mathrm{TiO}_{2}$ indicates a fairly homogeneous granular surface with fine grain boundaries. The crystals seem to be well-bonded to, and partially embedded in the matrix due to the shadow surrounding the crystals 

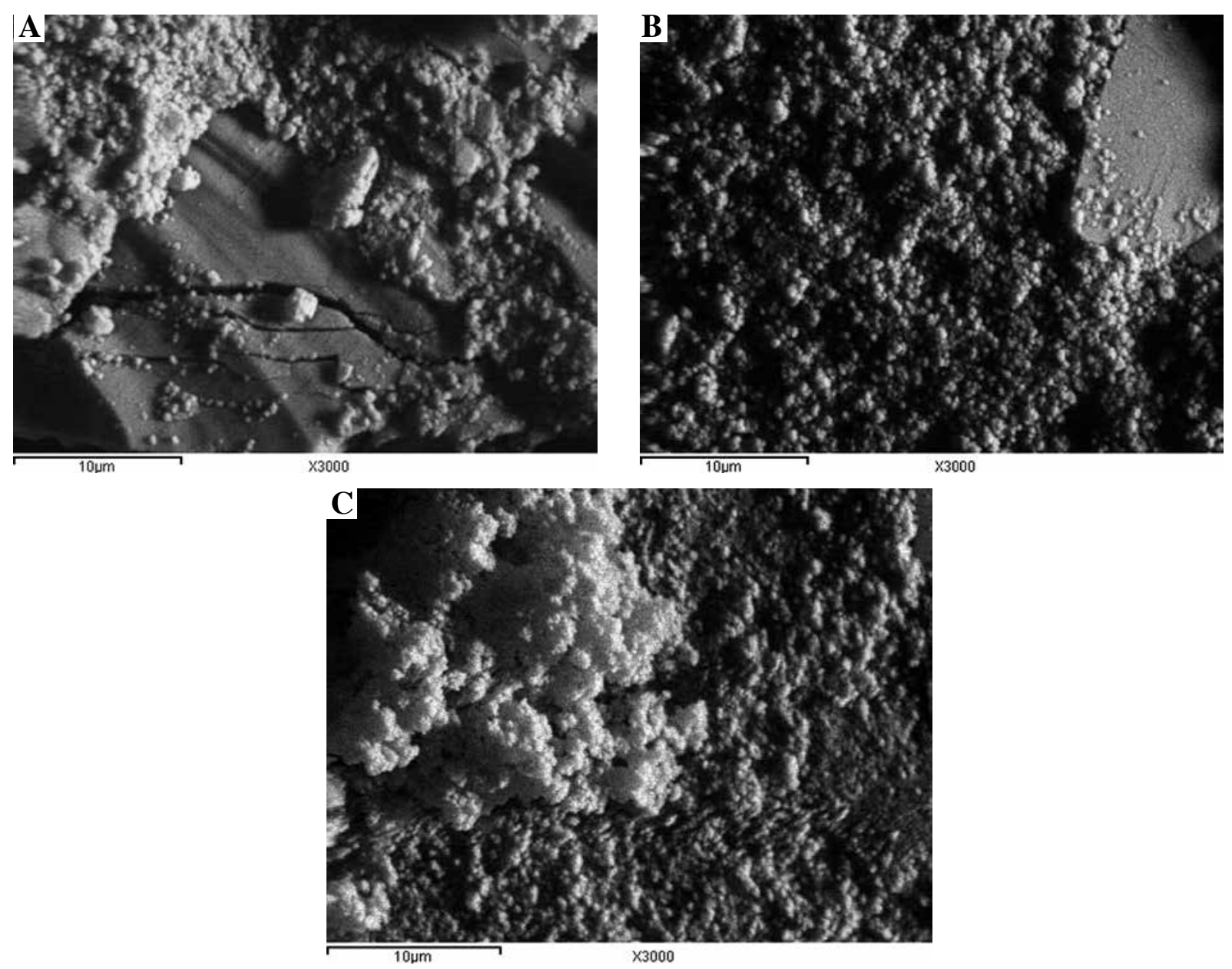

Fig. 3. SEM micrograph of $\mathrm{SiO}_{2}: \mathrm{TiO}_{2}$ composite of ratio $1: 1(\mathrm{~A}), 1: 2(\mathrm{~B})$, and $1: 3(\mathrm{C})$, respectively

speed up apatite nucleation by increasing the ionic activity product of the apatite in the fluid. As a result, the apatite layer formed on the composite surface after soaking in SBF was confirmed by SEM of the $\mathrm{SiO}_{2} / \mathrm{TiO}_{2}$ composites post-immersion as shown in Fig. 3. For ratio $1: 1$ composite, SEM at $3000 \times$ shows that it has many particles on its surface proving slight formation of apatite layer due to the high content of silica in the composite illustrating melted and dense structure that reduced the nucleation of apatite layer compared to other composites. In this domain, the simultaneous dissolution of silicates results in the formation of the silanol (Si-OH) groups on the material's surface, which are crucial as nucleation sites resulting in HA development [40]. Once the apatite nuclei form, they can grow instinctively by overwhelming the calcium phosphate (CaP) ions already found in the surrounding SBF fluid [41]. For biocomposites of ratio $1: 2$ and $1: 3$ the SEM at the same magnification indicates the presence of abundant spherical shapes formed in several layers accumulating over each other to form a bone-like apatite layer for both composites, especially those with the higher content of ti- tania. $\mathrm{TiO}_{2}$ has a propensity to adsorb water at its surface, resulting in the formation of titanium hydroxide (Ti-OH) groups, which were reported to persuade apatite nucleation and crystallisation in SBF [29]. This result may be due to the high content of titania, which leads to an upsurge of $\mathrm{Ti}-\mathrm{OH}$ groups at the expense of $\mathrm{Si}-\mathrm{OH}$ groups, resulting in the high nucleation of apatite [42]. The roughness of the surface increases with increasing concentration of $\mathrm{TiO}_{2}$ [43]. The thick layer is probably formed due to the large agglomerations of titania particles in these biocomposites (Fig. 3C), which may act as sites for the nucleation and growth of HA [17].

In addition, the results in Fig. 4B-D show the SEM micrograph of $\mathrm{SiO}_{2}: \mathrm{ZrO}_{2}$ composite of ratio $1: 1,1: 2$, and $1: 3$ at the same magnification $(3000 \times)$. The growth of the apatite layer, covering the surface of the zirconia substrate, was very poor. In addition, the smaller groups of a few clustered particles were formed on the substrate as shown in the figures. The coating has an imperfect structure and very low crystallinity [30]. 

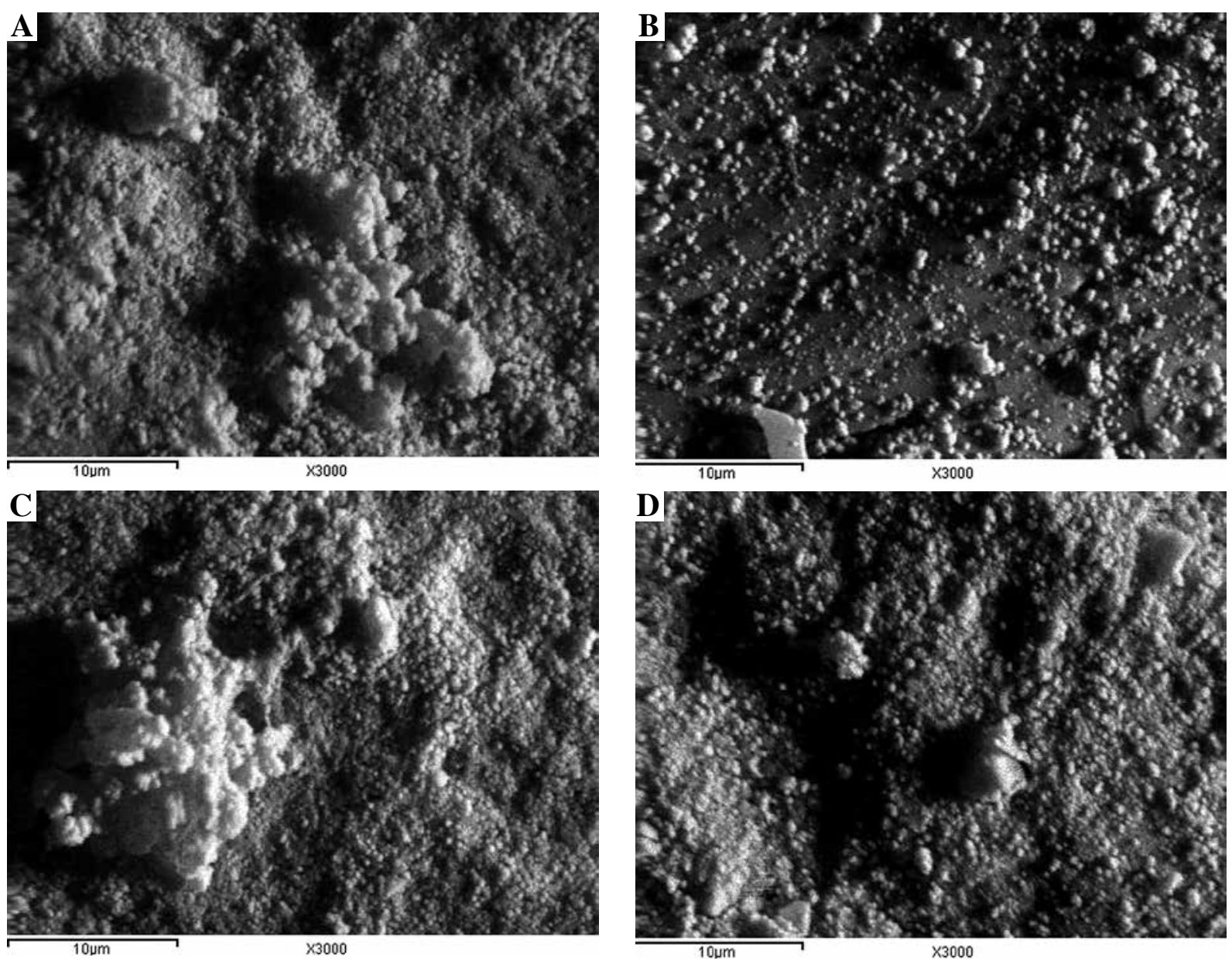

Fig. 4. Clearly visible characteristic accumulation of various sizes of spherical particles that covered the surface of pure zirconium (A); particles of $\mathrm{SiO}_{2}: \mathrm{ZrO}_{2} 1: 1$ (B); particles of $\mathrm{SiO}_{2}: \mathrm{ZrO}_{2} 1: 2$ (C); and particles of $\mathrm{SiO}_{2}: \mathrm{ZrO}_{2} 1: 3$ (D)

Table 2. Detected bands using ISSR analysis in male mice treated with high dose (400 mg/kg) of $\mathrm{SiO}_{2}, \mathrm{TiO}_{2}$, and $\mathrm{ZrO}_{2}-\mathrm{Ps}$

\begin{tabular}{lccccccc}
\hline Treatment & $\begin{array}{c}\text { Mobility range } \\
\text { bp }\end{array}$ & $\begin{array}{c}\text { Total band } \\
\text { Nos. }\end{array}$ & $\begin{array}{c}\text { Mean band } \\
(\mathbf{X} \pm \mathbf{S E M})\end{array}$ & $\begin{array}{c}\text { Mono- } \\
\text { morphic }\end{array}$ & $\begin{array}{c}\text { Mono- } \\
\text { morphic }(\%)\end{array}$ & $\begin{array}{c}\text { Poly- } \\
\text { morphic }\end{array}$ & $\begin{array}{c}\text { Poly- } \\
\text { morphic }(\%)\end{array}$ \\
\hline Control & $1360-168$ & 90 & $15.0 \pm 0.01$ & 84.0 & 93.3 & 6 & 6.7 \\
\hline Cyclophosphamide & $1392-112$ & 111 & $18.5 \pm 0.02$ & 74.0 & 66.7 & 37 & 33.3 \\
\hline $\mathrm{SiO}_{2}$ & $1354-157$ & 92 & $15.3 \pm 0.01$ & 79.0 & 85.9 & 13 & 14.1 \\
\hline $\mathrm{TiO}_{2}$ & $1387-114$ & 101 & $16.8 \pm 0.02$ & 77.0 & 76.2 & 24 & 23.8 \\
\hline $\mathrm{ZrO}_{2}$ & $1369-158$ & 94 & $15.7 \pm 0.01$ & 82.0 & 87.2 & 12 & 12.8 \\
\hline $\mathrm{SiO}_{2}: \mathrm{TiO}_{2}(1: 1)$ & $1372-152$ & 95 & $15.8 \pm 0.02$ & 79.0 & 83.2 & 16 & 16.8 \\
\hline $\mathrm{SiO}_{2}: \mathrm{TiO}_{2}(1: 2)$ & $1383-135$ & 96 & $16.0 \pm 0.01$ & 77.0 & 80.2 & 19 & 19.8 \\
\hline $\mathrm{SiO}_{2}: \mathrm{TiO}_{2}(1: 3)$ & $1389-117$ & 99 & $16.5 \pm 0.01$ & 75.0 & 75.8 & 24 & 24.2 \\
\hline $\mathrm{SiO}_{2}: \mathrm{ZrO}_{2}(1: 1)$ & $1358-156$ & 92 & $15.3 \pm 0.01$ & 80.0 & 87.0 & 12 & 13.0 \\
\hline $\mathrm{SiO}_{2}: \mathrm{ZrO}_{2}(1: 2)$ & $1372-152$ & 92 & $15.3 \pm 0.01$ & 79.0 & 85.9 & 13 & 14.1 \\
\hline $\mathrm{SiO}_{2}: \mathrm{ZrO}_{2}(1: 3)$ & $1378-134$ & 95 & $15.8 \pm 0.02$ & 78.0 & 82.1 & 17 & 17.9 \\
\hline
\end{tabular}




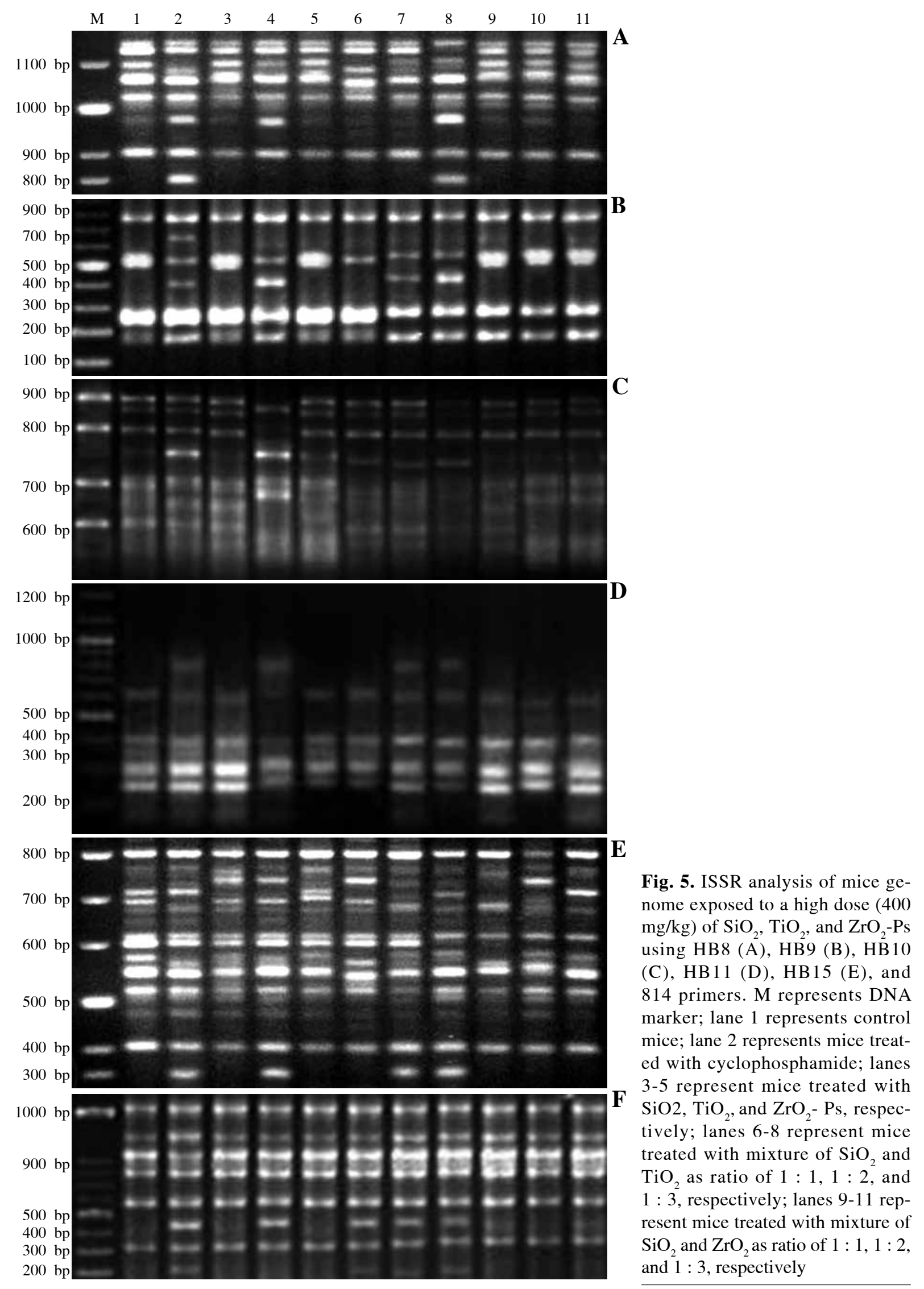




\section{In vivo study}

\section{ISSR analysis}

ISSR analysis was carried out in male mice using six anchor primers (HB8, HB9, HB10, HB11, HB15, and 814) to determine the genetic variation induced by treatment with mixed and unmixed $\mathrm{SiO}_{2}, \mathrm{TiO}_{2}$, and $\mathrm{ZrO}_{2-}$ Ps. The current study revealed no differences observed between untreated mice and those treated with low or medium doses of unmixed and mixed $\mathrm{SiO}_{2}, \mathrm{TiO}_{2}$, and $\mathrm{ZrO}_{2}$-Ps. Exceptionally, the highest dose $(400 \mathrm{mg} / \mathrm{kg}$ b.w.) of unmixed and mixed $\mathrm{SiO}_{2}, \mathrm{TiO}_{2}$, and $\mathrm{ZrO}_{2}$-Ps caused significant differences compared with the control mice, as summarised in Fig. 5 and Table 2. Untreated mice revealed the highest percentage of the monomorphic bands (93.3\%) and lowest percentage $(6.7 \%)$ of the polymorphic bands (Table 2 ). However, the highest percentage of the polymorphic bands was observed in mice treated with $\mathrm{CP}, \mathrm{TiO}_{2}$, and the mixture $1 \mathrm{SiO}_{2}: 3 \mathrm{TiO}_{2}$ $(33.3 \%, 23.8 \%$ and $24.2 \%$, respectively) (Table 2$)$.

\section{Micronucleus (MN) assay}

Figure 6 summarises the effect of $\mathrm{SiO}_{2}, \mathrm{TiO}_{2}$, and $\mathrm{ZrO}_{2}$ Ps in mixed and unmixed form on MnPCE formation in the bone marrow cells of male mice. The results showed that low and medium doses of mixed and unmixed $\mathrm{SiO}_{2}, \mathrm{TiO}_{2}$, and $\mathrm{ZrO}_{2}$-Ps did not increase significantly the incidence of MnPCEs in comparison to the control group (Fig. 6). However, exposure of male mice with high doses of $\mathrm{TiO}_{2}-$ Ps alone or in combination with $\mathrm{SiO}_{2}$-Ps with the ratio of $1: 1,2: 1$, and $3: 1$ increased significantly the incidence of MnPCEs $(11.6 \pm 0.1,10.9 \pm 0.2 ; 11.5 \pm 0.1$, and $13.3 \pm 0.3$, respectively) compared with that of the control group (4.9 \pm 0.1 , Fig. 6$)$. On the other hand, treatment of male mice with high doses of $\mathrm{SiO}_{2}$ - and $\mathrm{ZrO}_{2}$-Ps alone or in combination with each other with the ratio of $1: 1$, $1: 2$, and $1: 3$ did not increase significantly the MnPCEs formation in the bone marrow cells (Fig. 6).

\section{Comet assay in liver tissues}

The genotoxic effect of $\mathrm{SiO}_{2}, \mathrm{TiO}_{2}$, and $\mathrm{ZrO}_{2}-\mathrm{Ps}$ in mixed and unmixed form in male mice is summarised in Table 3. The hepatic tissues of male mice exposed to $\mathrm{SiO}_{2}$, $\mathrm{TiO}_{2}$, and $\mathrm{ZrO}_{2}-\mathrm{Ps}$ showed considerable dose-dependent DNA damage when estimated by comet assay for DNA strand break in nuclei from individual cells. The results showed that there were no significant differences in the DNA damage values caused by low and medium doses of mixed and unmixed $\mathrm{SiO}_{2}, \mathrm{TiO}_{2}$, and $\mathrm{ZrO}_{2}$-Ps and even the control group. Conversely, DNA damaged cells were significantly high in mice exposed to the highest dose of $\mathrm{TiO}_{2}$ Ps (19\%) and $1 \mathrm{SiO}_{2}: 3 \mathrm{TiO}_{2}(20 \%)$, compared to control mice $(9 \%)$ (Table 1). Furthermore, the DNA damaged cells categorised as class 3 were also higher in mice exposed to $\mathrm{TiO}_{2}-\mathrm{Ps}$ and $1 \mathrm{SiO}_{2}: 3 \mathrm{TiO}_{2}$ than in other groups, except for the group exposed to cyclophosphamide (Table 3 ).
In addition, the DNA damaged cells in mice exposed to $400 \mathrm{mg} / \mathrm{kg}$ of $1 \mathrm{SiO}_{2}: 12 \mathrm{TiO}_{2}$ and $1 \mathrm{SiO}_{2}: 2 \mathrm{TiO}_{2}$ were increased but without significant differences (Table 1). On the other hand, other Ps were not able to significantly increase the DNA damage in hepatic cells of male mice, which were relatively similar to those of the control fish.

\section{Determination of glutathione peroxidase activity}

Table 4 shows the results of glutathione peroxidase activity after treatment of male mice with mixed and unmixed $\mathrm{SiO}_{2}, \mathrm{TiO}_{2}$, and $\mathrm{ZrO}_{2}$-Ps. The present study showed that male mice exposed to mixed or unmixed $\mathrm{SiO}_{2}, \mathrm{TiO}_{2}$, and $\mathrm{ZrO}_{2}$-Ps in low and medium doses had relatively similar values to untreated mice (data not shown). However, the values of glutathione peroxidase activity showed significant differences with the treatment of the highest dose of $\mathrm{SiO}_{2}, \mathrm{TiO}_{2}$ and $\mathrm{ZrO}_{2}$-Ps, where treatment of male mice with $\mathrm{TiO}_{2}$-Ps either in unmixed form or mixed form with $\mathrm{SiO}_{2}$ decreased significantly the values of glutathione peroxidase activity (Table 4). However, other types of the used Ps did not induce significant reduction in the glutathione peroxidase activity with $400 \mathrm{mg} / \mathrm{kg}$, whereas the activity values in mice treated with $\mathrm{SiO}_{2}$ and $\mathrm{ZrO}_{2}$-Ps were similar to those in untreated mice (Table 4).

\section{Determination of albumin, globulin, and $A / G$ ratio}

Table 5 represents the results of albumin, globulin, and $\mathrm{A} / \mathrm{G}$ ratio after treatment of male mice with mixed and unmixed $\mathrm{SiO}_{2}, \mathrm{TiO}_{2}$, and $\mathrm{ZrO}_{2}$-Ps. The results found that male mice exposed to mixed or unmixed $\mathrm{SiO}_{2}, \mathrm{TiO}_{2}$, and $\mathrm{ZrO}_{2}-\mathrm{Ps}$ in low and medium doses had relatively similar values of albumin, globulin, and A/G to untreated mice (data not shown). In contrast, the values of albumin, globulin, and A/G showed significant differences with the treatment of the highest dose $(400 \mathrm{mg} / \mathrm{kg})$ of $\mathrm{SiO}_{2}, \mathrm{TiO}_{2}$, and $\mathrm{ZrO}_{2}-\mathrm{Ps}$, in which treatment of male mice with $\mathrm{TiO}_{2}-\mathrm{Ps}$ either in unmixed form or mixed form with $\mathrm{SiO}_{2}$ decreased significantly the levels of albumin and globulin (Table 5). However, other types of used Ps did not prompt significant changes in the levels of albumin and globulin with $400 \mathrm{mg} /$ $\mathrm{kg}$ compared with control mice (Table 5).

\section{Assessment the population of lymphocytes in peripheral blood}

Figure 7 exemplifies the results of the distribution of lymphocyte population in the peripheral blood of male mice exposed to mixed and unmixed $\mathrm{SiO}_{2}, \mathrm{TiO}_{2}$, and $\mathrm{ZrO}_{2}$-Ps. male mice exposed to mixed or unmixed $\mathrm{SiO}_{2}$, $\mathrm{TiO}_{2}$, and $\mathrm{ZrO}_{2}-\mathrm{Ps}$ in low and medium doses had relatively analogous values to untreated mice (data not shown). At the highest dose of $\mathrm{SiO}_{2}, \mathrm{TiO}_{2}$, and $\mathrm{ZrO}_{2-}$ Ps the results revealed that no significant differences were found in the distribution of T-cell and NK-cell populations between treated and control animals $(p>0.05)$. However, distribution 


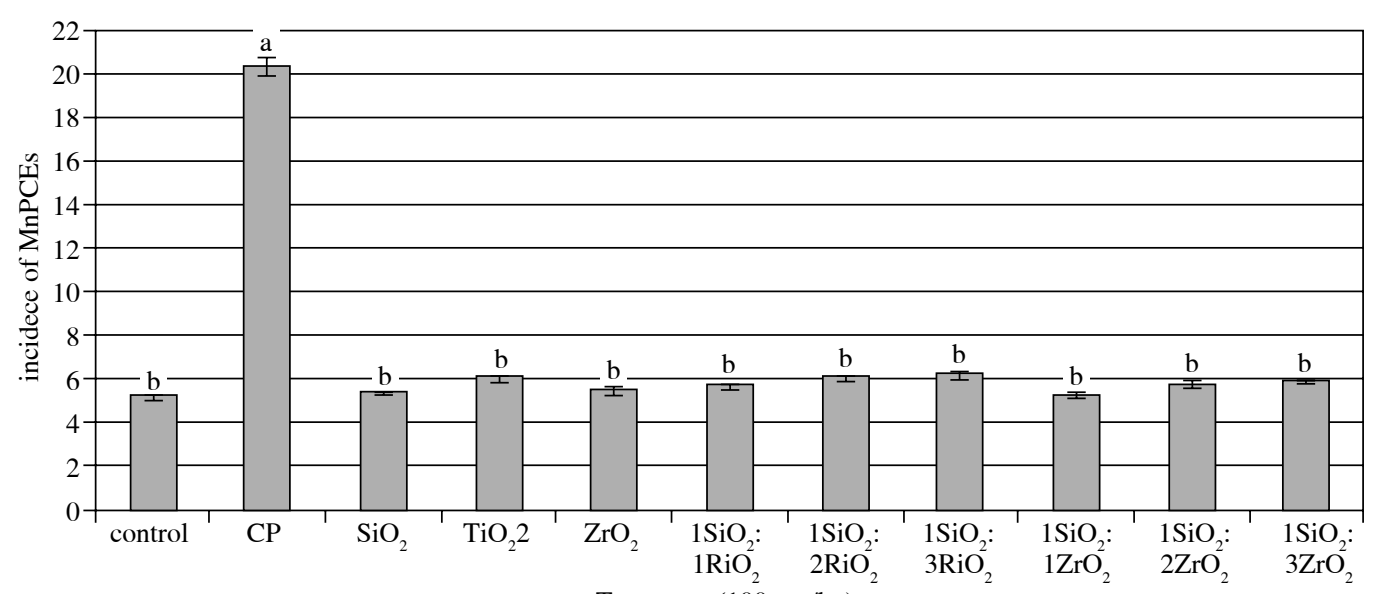

Treatment $(100 \mathrm{mg} / \mathrm{kg})$
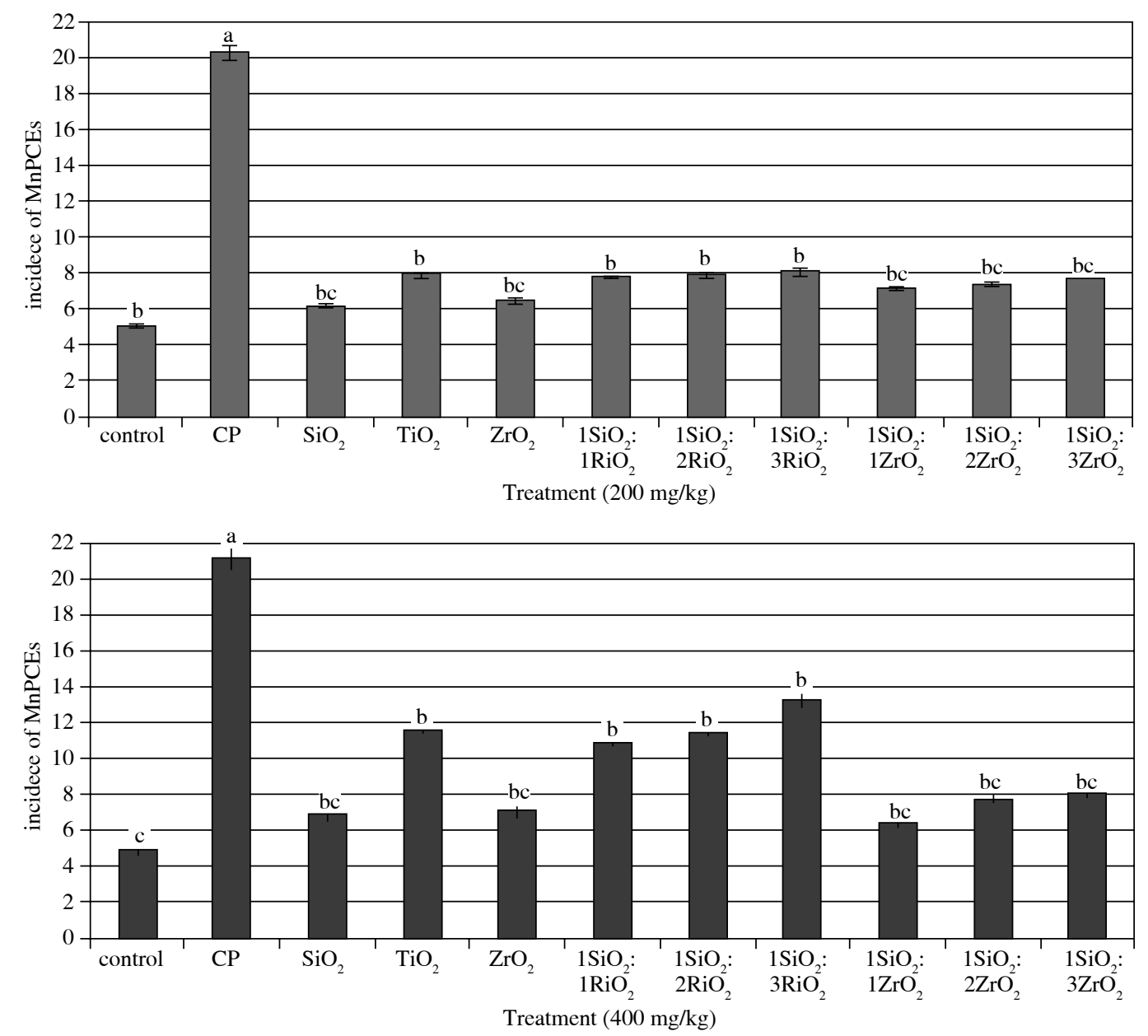

\section{CP-cyclophosphamide}

Fig. 6. Micronucleated polychromatic erythrocytes (MnPCEs) of male mice exposed to different doses of $\mathrm{SiO}_{2}, \mathrm{TiO}_{2}$, and $\mathrm{ZrO}_{2}$-Ps. Results are expressed as mean \pm SEM of data from at least ten samples. Mean values within tissue with unlike superscript letters were significantly different $(p<0.05$, Scheffé-Test) (A-C). Mean values within tissue with similar superscript letters were not significant differences $(p>0.05)(B, C)$ 
Table 3. Visual score of DNA damage in male mice exposed to high dose (400 mg/kg) of $\mathrm{SiO}_{2}, \mathrm{TiO}_{2}$, and $\mathrm{ZrO}_{2}-\mathrm{Ps}$

\begin{tabular}{cccccccc}
\hline Treatment & \multicolumn{2}{c}{ No. of cells } & \multicolumn{2}{c}{ Class $\Omega$} & DNA damaged cells \\
\cline { 2 - 6 } & Analysed & Comet & $\mathbf{0}$ & $\mathbf{1}$ & $\mathbf{2}$ & $\mathbf{3}$ mean $)$ \\
\hline Control & 100 & 9 & 91 & 6 & 3 & 0 & $9 \mathrm{c}$ \\
\hline Cyclophosphamide & 100 & 29 & 71 & 8 & 7 & 14 & $29 \mathrm{a}$ \\
\hline $\mathrm{SiO}_{2}$ & 100 & 10 & 90 & 5 & 4 & 1 & $10 \mathrm{c}$ \\
\hline $\mathrm{TiO}_{2}$ & 100 & 19 & 81 & 4 & 6 & 9 & $19 \mathrm{~b}$ \\
\hline $\mathrm{ZrO}_{2}$ & 100 & 11 & 89 & 5 & 3 & 3 & $11 \mathrm{c}$ \\
\hline $\mathrm{SiO}_{2}: \mathrm{TiO}_{2}(1: 1)$ & 100 & 12 & 88 & 3 & 5 & 4 & $12 \mathrm{c}$ \\
\hline $\mathrm{SiO}_{2}: \mathrm{TiO}_{2}(1: 2)$ & 100 & 15 & 85 & 5 & 4 & 6 & $15 \mathrm{bc}$ \\
\hline $\mathrm{SiO}_{2}: \mathrm{TiO}_{2}(1: 3)$ & 100 & 20 & 80 & 1 & 7 & 12 & $20 \mathrm{~b}$ \\
\hline $\mathrm{SiO}_{2}: \mathrm{ZrO}_{2}(1: 1)$ & 100 & 10 & 90 & 4 & 3 & 3 & $10 \mathrm{c}$ \\
\hline $\mathrm{SiO}_{2}: \mathrm{ZrO}_{2}(1: 2)$ & 100 & 12 & 88 & 6 & 2 & 4 & $12 \mathrm{c}$ \\
\hline & 100 & 14 & 86 & 5 & 4 & 5 & $14 \mathrm{bc}$ \\
\hline
\end{tabular}

: Class $0=$ no tail; $1=$ tail length $<$ diameter of nucleus; $2=$ tail length between $1 \times$ and $2 \times$ the diameter of nucleus; and $3=$ tail length $>2 \times$ the diameter of nucleus.

Table 4. The amount of glutathione peroxidase activity in mice exposed to $\mathrm{SiO}_{2}, \mathrm{TiO}_{2}$, and $\mathrm{ZrO}_{2} \mathrm{Ps}$ (mg/kg b.w.).

\begin{tabular}{|c|c|c|c|}
\hline \multirow[t]{2}{*}{ Treatment* } & \multicolumn{3}{|c|}{ Glutathione peroxidase activity (U/mg tissues/min) } \\
\hline & $100 *$ & 200* & $400^{*}$ \\
\hline Control & $5.5 \pm 0.02^{\mathrm{a}}$ & $5.4 \pm 0.03^{\mathrm{a}}$ & $5.7 \pm 0.01^{\mathrm{a}}$ \\
\hline Cyclophosphamide & $1.7 \pm 0.05^{\mathrm{b}}$ & $1.7 \pm 0.04^{\mathrm{b}}$ & $1.6 \pm 0.05^{\mathrm{c}}$ \\
\hline $\mathrm{SiO}_{2}$ & $5.4 \pm 0.04^{\mathrm{a}}$ & $5.1 \pm 0.05^{\mathrm{a}}$ & $4.9 \pm 0.03^{\mathrm{a}}$ \\
\hline $\mathrm{TiO}_{2}$ & $5.0 \pm 0.03^{\mathrm{a}}$ & $4.8 \pm 0.04^{\mathrm{a}}$ & $2.7 \pm 0.04^{\mathrm{b}}$ \\
\hline $\mathrm{ZrO}_{2}$ & $5.2 \pm 0.03^{\mathrm{a}}$ & $5.1 \pm 0.04^{\mathrm{a}}$ & $4.4 \pm 0.03^{\mathrm{ab}}$ \\
\hline $\mathrm{SiO}_{2}: \mathrm{TiO}_{2}(1: 1)$ & $5.2 \pm 0.04^{\mathrm{a}}$ & $4.8 \pm 0.03^{\mathrm{a}}$ & $2.9 \pm 0.02^{\mathrm{b}}$ \\
\hline $\mathrm{SiO}_{2}: \mathrm{TiO}_{2}(1: 2)$ & $4.9 \pm 0.02^{\mathrm{a}}$ & $4.7 \pm 0.05^{\mathrm{a}}$ & $2.6 \pm 0.03^{\mathrm{b}}$ \\
\hline $\mathrm{SiO}_{2}: \mathrm{TiO}_{2}(1: 3)$ & $4.8 \pm 0.05^{\mathrm{a}}$ & $4.5 \pm 0.06^{\mathrm{a}}$ & $2.3 \pm 0.02^{\mathrm{b}}$ \\
\hline $\mathrm{SiO}_{2}: \mathrm{ZrO}_{2}(1: 1)$ & $5.2 \pm 0.05^{\mathrm{a}}$ & $5.1 \pm 0.06^{\mathrm{a}}$ & $4.2 \pm 0.04^{\mathrm{ab}}$ \\
\hline $\mathrm{SiO}_{2}: \mathrm{ZrO}_{2}(1: 2)$ & $5.1 \pm 0.06^{\mathrm{a}}$ & $4.9 \pm 0.04^{\mathrm{a}}$ & $4.1 \pm 0.05^{\mathrm{ab}}$ \\
\hline $\mathrm{SiO}_{2}: \mathrm{ZrO}_{2}(1: 3)$ & $5.0 \pm 0.04^{\mathrm{a}}$ & $4.8 \pm 0.06^{\mathrm{a}}$ & $4.0 \pm 0.02^{\mathrm{ab}}$ \\
\hline
\end{tabular}

${ }^{*}$ Each treatment had an equivalent numbers of animals $(n=10)$

a,b,c Mean values within tissue with unlike superscript letters were significantly different $(p<0.05$, Scheffe-Test)

${ }_{a, b, a b}$ Mean values within tissue with similar superscript letters were not significant differences $(p>0.05)$

of B-cell population was increased significantly $(p<0.05)$ with $\mathrm{TiO}_{2}$ treatment either in mixed or unmixed forms.

\section{Determination of ALT and AST}

Table 6 represents the parameters of liver function (ALT and AST) after treatment of male mice with both mixed and unmixed $\mathrm{SiO}_{2}, \mathrm{TiO}_{2}$, and $\mathrm{ZrO}_{2-}$ Ps. The results showed that mice exposed to mixed or unmixed $\mathrm{SiO}_{2}, \mathrm{TiO}_{2}$, and $\mathrm{ZrO}_{2}$ Ps in low and medium doses had values of ALT and AST relatively comparable to control mice (data not shown). However, the values of ALT and AST showed significant variance with the treatment of the highest dose $(400 \mathrm{mg} / \mathrm{kg})$ of $\mathrm{SiO}_{2}, \mathrm{TiO}_{2}$, and $\mathrm{ZrO}_{2} \mathrm{Ps}$, in which treatment of mice with $\mathrm{TiO}_{2}$-Ps either in unmixed form or mixed form with $\mathrm{SiO}_{2}$ increased significantly the levels of ALT and AST (Table 6). However, other types of the used Ps did not give significant changes in the levels of ALT and AST with $400 \mathrm{mg} / \mathrm{kg}$ compared with control mice (Table 5).

\section{Discussion}

Although great developments have been made in the worldwide production and use of metal-based composites 
Table 5. Levels of Albumin, globulin, and A/G ration in serum of male mice exposed to $\mathrm{SiO}_{2}, \mathrm{TiO}_{2}$, and $\mathrm{ZrO}-\mathrm{Ps}(\mathrm{mg} /$ kg b.w.)

\begin{tabular}{cccc}
\hline Treatment* & Particulars & \\
\cline { 2 - 4 } & Albumin & Globulin & A/G ratio \\
\hline Control & $5.7 \pm 0.3^{\mathrm{a}}$ & $3.2 \pm 0.1^{\mathrm{a}}$ & $1.26 \pm 0.2^{\mathrm{b}}$ \\
\hline Cyclophosphamide & $2.3 \pm 0.4^{\mathrm{b}}$ & $1.8 \pm 0.2^{\mathrm{b}}$ & $1.54 \pm 0.3^{\mathrm{ab}}$ \\
\hline $\mathrm{SiO}_{2}$ & $4.9 \pm 0.2^{\mathrm{a}}$ & $3.0 \pm 0.3^{\mathrm{a}}$ & $1.32 \pm 0.2^{\mathrm{a}}$ \\
\hline $\mathrm{TiO}_{2}$ & $3.2 \pm 0.3^{\mathrm{ab}}$ & $2.3 \pm 0.4^{\mathrm{ab}}$ & $1.68 \pm 0.1^{\mathrm{a}}$ \\
\hline $\mathrm{ZrO}_{2}$ & $4.6 \pm 0.5^{\mathrm{a}}$ & $2.8 \pm 0.3^{\mathrm{a}}$ & $1.42 \pm 0.4^{\mathrm{ab}}$ \\
\hline $\mathrm{SiO}_{2}: \mathrm{TiO}_{2}(1: 1)$ & $4.3 \pm 0.3^{\mathrm{a}}$ & $2.7 \pm 0.2^{\mathrm{a}}$ & $1.48 \pm 0.2^{\mathrm{ab}}$ \\
\hline $\mathrm{SiO}_{2}: \mathrm{TiO}_{2}(1: 2)$ & $3.9 \pm 0.1^{\mathrm{a}^{\mathrm{ab}}}$ & $2.5 \pm 0.1^{\mathrm{a}}$ & $1.84 \pm 0.2^{\mathrm{a}}$ \\
\hline $\mathrm{SiO}_{2}: \mathrm{TiO}_{2}(1: 3)$ & $3.1 \pm 0.4^{\mathrm{ab}^{\mathrm{a}}}$ & $2.0 \pm 0.3^{\mathrm{b}}$ & $1.96 \pm 0.3^{\mathrm{a}}$ \\
\hline $\mathrm{SiO}_{2}: \mathrm{ZrO}_{2}(1: 1)$ & $4.6 \pm 0.6^{\mathrm{a}}$ & $2.9 \pm 0.4^{\mathrm{a}}$ & $1.33 \pm 0.1^{\mathrm{ab}}$ \\
\hline $\mathrm{SiO}_{2}: \mathrm{ZrO}_{2}(1: 2)$ & $4.1 \pm 0.5^{\mathrm{a}}$ & $2.6 \pm 0.2^{\mathrm{ab}}$ & $1.38 \pm 0.3^{\mathrm{ab}}$ \\
\hline $\mathrm{SiO}_{2}: \mathrm{ZrO}_{2}(1: 3)$ & $3.8 \pm 0.3^{\mathrm{ab}}$ & $2.4 \pm 0.1^{\mathrm{ab}}$ & $1.41 \pm 0.1^{\mathrm{ab}}$ \\
\hline
\end{tabular}

$\overline{a, b, c}$ Mean values within tissue with unlike superscript letters were significantly different $(p<0.05$, Scheffé-Test)

${ }^{a, b, a b}$ Mean values within tissue with similar superscript letters were not significant differences $(p>0.05)$

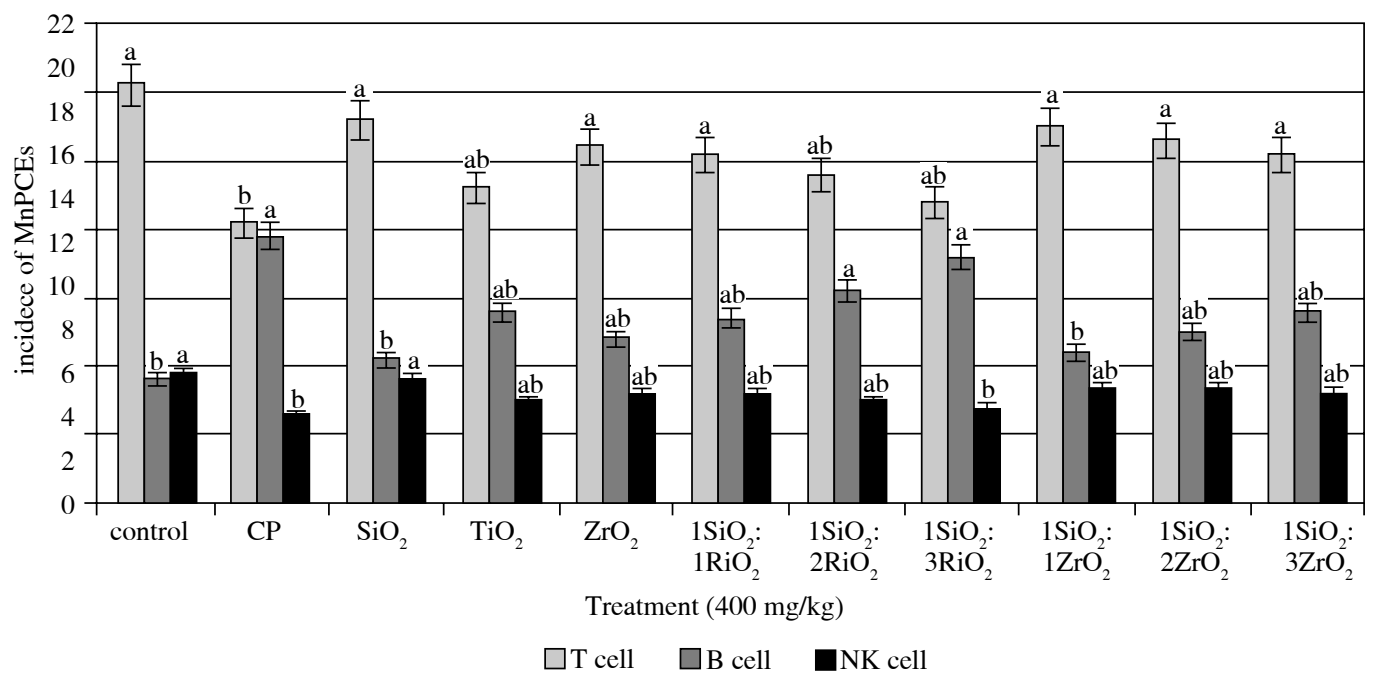

Fig. 7. Population of lymphocyte distribution of peripheral blood from male mice exposed to different doses of $\mathrm{SiO}_{2}$, $\mathrm{TiO}_{2}$, and $\mathrm{ZrO}_{2}-\mathrm{Ps}$

and nanoparticles, there is a serious lack of information about the impact of these materials on human health and environment, especially the potential for induced toxicity [44]. Preliminary reports of the inherent toxicity of some metals nanoparticles (NPs) are available and indicate that they can affect biological behaviour at the organ, tissue, cellular, subcellular, and protein levels.

Schrand et al. [45] reported that as particle size decreases, some metal-based NPs showed increment in their toxicity. NPs also interact with proteins and enzymes within mammalian cells and interfere with the antioxidant defence mechanism leading to reactive oxygen species generation, the initiation of an inflammatory response, and perturbation and destruction of the mitochondria causing apoptosis or necrosis. Therefore, the main objective of the current study was to use larger particles than nanoparticles to decrease the risk of the potential toxicity attributed to the use of small particles of materials under study.

The present work showed that the treatment of male mice with $\mathrm{SiO}_{2}$ and $\mathrm{ZrO}_{2}$ in separate or in mixture form exhibited lower toxicity values than those resulting from $\mathrm{TiO}_{2}$. Furthermore, the present study demonstrated that 100 and $200 \mathrm{mg} / \mathrm{kg}$ b.w. of $\mathrm{SiO}_{2}, \mathrm{TiO}_{2}$, and $\mathrm{ZrO}_{2}$ - Ps in ei- 
Table 6. Levels of hepatic factors in male mice exposed to high dose $(400 \mathrm{mg} / \mathrm{kg})$ of $\mathrm{SiO}_{2}, \mathrm{TiO}_{2}$, and $\mathrm{ZrO}_{2} \mathrm{Ps}$

\begin{tabular}{|c|c|c|}
\hline \multirow[t]{2}{*}{ Treatment* } & \multicolumn{2}{|c|}{ Hepatic factors } \\
\hline & ALT (U/l) & $\operatorname{AST}(\mathbf{U} / \mathbf{l})$ \\
\hline Control & $23 \pm 1.2^{b}$ & $72 \pm 4.2^{\mathrm{c}}$ \\
\hline Cyclophosphamide & $42 \pm 2.7^{\mathrm{a}}$ & $173 \pm 4.2^{\mathrm{a}}$ \\
\hline $\mathrm{SiO}_{2}$ & $26 \pm 1.4^{b}$ & $81 \pm 2.5^{\mathrm{c}}$ \\
\hline $\mathrm{TiO}_{2}$ & $34 \pm 1.6^{\mathrm{ab}}$ & $142 \pm 3.4^{b}$ \\
\hline $\mathrm{ZrO}_{2}$ & $28 \pm 2.3^{\mathrm{ab}}$ & $83 \pm 3.1^{\mathrm{c}}$ \\
\hline $\mathrm{SiO}_{2}: \mathrm{TiO}_{2}(1: 1)$ & $29 \pm 2.2^{\mathrm{ab}}$ & $121 \pm 4.1^{\mathrm{b}}$ \\
\hline $\mathrm{SiO}_{2}: \mathrm{TiO}_{2}(1: 2)$ & $33 \pm 1.9^{a b}$ & $138 \pm 3.4^{\mathrm{b}}$ \\
\hline $\mathrm{SiO}_{2}: \mathrm{TiO}_{2}(1: 3)$ & $38 \pm 3.1^{\mathrm{a}}$ & $149 \pm 4.5^{\mathrm{b}}$ \\
\hline $\mathrm{SiO}_{2}: \mathrm{ZrO}_{2}(1: 1)$ & $24 \pm 2.1^{\mathrm{b}}$ & $79 \pm 1.1^{\mathrm{c}}$ \\
\hline $\mathrm{SiO}_{2}: \mathrm{ZrO}_{2}(1: 2)$ & $27 \pm 2.4^{\mathrm{ab}}$ & $87 \pm 2.9^{c}$ \\
\hline $\mathrm{SiO}_{2}: \mathrm{ZrO}_{2}(1: 3)$ & $30 \pm 2.7^{\mathrm{ab}}$ & $89 \pm 2.4^{c}$ \\
\hline $\begin{array}{l}\text { Mean values within tiss } \\
\text { ifferent }(p<0.05, \text { Scheff } \\
\text { gnificant differences }(p>\end{array}$ & $\begin{array}{l}\text { ke superscr } \\
\text { similar su }\end{array}$ & $\begin{array}{l}\text { ere significa } \\
\text { etters were }\end{array}$ \\
\hline
\end{tabular}

ther mixed or unmixed form were safe in male mice using several genotoxicity and biochemical assays. However, using $400 \mathrm{mg} / \mathrm{kg}$ of $\mathrm{TiO}_{2}$-Ps in unmixed form or mixed with $\mathrm{SiO}_{2}$ increased the toxicity potential using ISSR analysis, micronucleus test, comet assay, and glutathione peroxidase activity. In good agreement with our work, Heckmann et al. [46] reported that $\mathrm{TiO}_{2}$ particles were the only metal that initiated toxic effects to earthworms compared with other metals, such as $\mathrm{Ag}, \mathrm{Cu}, \mathrm{Ni}, \mathrm{Al}_{2} \mathrm{O}_{3}, \mathrm{SiO}_{2}$, and $\mathrm{ZrO}_{2}$ particles. In addition, $\mathrm{TiO}_{2}-\mathrm{NP}$ has previously been reported to induce toxicity to bacteria [47] and the freshwater crustacean Daphnia magna [48].

Conversely, a recent study by Lindberg et al. [49] demonstrated that inhalation of mice with nano-sized $\mathrm{TiO}_{2}$ (74\% anatase, $26 \%$ brookite; five days, four hours/day) resulted in a clear increase in neutrophils in BAL (mouse bronchoalveolar lavage) fluid, indicating an inflammatory effect; however, no significant effect on the level of DNA damage in lung epithelial cells or micronuclei in PCEs was observed. They suggested that inhalation exposure resulted in much lower systemic $\mathrm{TiO}_{2}$ doses than the IP injection and intraperitoneal treatments. Therefore, the lung epithelial cells probably received considerably less $\mathrm{TiO}_{2}$ than $\mathrm{BAL}$ cells. These findings support our results, in which the mice in the present experiment were treated IP and consequently had greater toxicity than inhalation exposure. Another recent study by Sadiq et al. [50] reported that $\mathrm{TiO}_{2}$ can reach the mouse bone marrow and is prone to inducing cytotoxicity. These results were obtained when mice were treated intravenously with three daily doses of $50 \mathrm{mg} / \mathrm{kg}$ $\mathrm{TiO}_{2}$ NPs.
These results demonstrate that nanoparticles of $\mathrm{TiO}_{2}$ can potentially cause adverse effects on organ, tissue, cellular, subcellular, and protein levels due to their unusual physicochemical properties, such as small size [45]. However, our study found that genotoxicity of $\mathrm{TiO}_{2}$ was observed only with the highest dose $(400 \mathrm{mg} / \mathrm{kg})$ of $\mathrm{TiO}_{2}$ particles; treatment of male mice in the current study with 100 or $200 \mathrm{mg} / \mathrm{kg}$ of $\mathrm{TiO}_{2}$ particles did not cause any genotoxicity symptoms. These results suggest that as particle size decreases, some metals show increased toxicity, even if the same material is relatively inert in its bulk form [45].

Moreover, an explanation for the mechanism thought to be responsible for the genetic alterations exerted by $\mathrm{TiO}_{2}$ involves oxidative stress, in which several studies showed that $\mathrm{TiO}_{2}$ induced reactive oxygen species (ROS) in a variety of cell types and tissues [51-56]. Our results are in a good settlement with these findings, where $\mathrm{TiO}_{2}$ inhibits the antioxidant activity of the glutathione peroxidase enzyme. It is increasingly proposed that ROS and reactive nitrogen species (RNS) play a vital role in DNA damage and cancer development [57, 58].

Reactive oxygen species is a collective term often used by biologists to include oxygen radicals [superoxide $\left(\mathrm{O}_{2}\right)$, hydroxyl $(\mathrm{OH})$, peroxyl $\left(\mathrm{RO}_{2}\right)$, and alkoxyl $\left.(\mathrm{RO})\right]$ and certain nonradicals that are either oxidising agents and/or are easily converted into radicals, such as $\mathrm{HOCl}$, ozone $\left(\mathrm{O}_{3}\right)$, peroxynitrite (ONOO-), singlet oxygen $\left({ }^{1} \mathrm{O}_{2}\right)$, and $\mathrm{H}_{2} \mathrm{O}_{2}$. The mechanism of ROS inducing DNA damage could be attributed to one or more reasons as follows: (1) ROS causes structural alterations in DNA, e.g. base pair mutations, rearrangements, deletions, insertions, and sequence amplification [58]; (2) affect cytoplasmic and nuclear signal transduction pathways $[59,58]$; and (3) modulate the activity of the proteins and genes that respond to stress and act to regulate the genes that are related to cell proliferation, differentiation, and apoptosis [59, 58].

The immune organs and cells play a vigorous role during the body defence progress for xenobiotics. The present study revealed that treatment of male mice with $\mathrm{TiO}_{2}-\mathrm{Ps}$ either in mixed of unmixed forms of $\mathrm{SiO}_{2}$ decreased significantly the levels of albumin and globulin and increased the B-cell population as well as ALT and AST in the mice samples. In agreement with our findings, in mice treated with nano- $\mathrm{TiO}_{2}$, their liver showed congestion and other diseases, as well as decreased levels of albumin, globulin and levels of leucocytes and T cells, glutamate aminotransferase, and AST, which are all related to liver function. These results indicate that $\mathrm{TiO}_{2}$ impairs the immunity of the liver and alters liver function [60]. In addition, Li et al. reported that exposure to $\mathrm{TiO}_{2}$ by intraperitoneal injection induced obvious congestion and lymph nodule proliferation in the mouse spleen [61]. These results indicated that exposure to $\mathrm{TiO}_{2}$ particles could translocate throughout the body quickly and tend to accumulate in immune organs, possibly through uptake by migratory antigen presenting cells, because many 
toxicological studies have observed that macrophages or foreign-body giant cells appeared in lung tissue as exposure doses increased [62].

In conclusion, the current study found that $\mathrm{TiO}_{2}$ composite induced in vivo immune and genetic toxicity in a dose-dependent manner in mice. However, $\mathrm{SiO}_{2}$, and $\mathrm{ZrO}_{2}$ composites revealed a lower toxicity in male mice compared to $\mathrm{TiO}_{2}$. These data suggest that $\mathrm{SiO}_{2}$ and $\mathrm{ZrO}_{2}$ composites expressed a low toxicity rate and could be used in biomedical applications such as repair bone defects. Moreover, we should be concerned about the potential risk of cancer or genetic disorders especially for people occupationally exposed to high concentrations of $\mathrm{TiO}_{2}$, and that it might be prudent to limit ingestion of $\mathrm{TiO}_{2}$ through nonessential drug additives, food colourings, etc.

The project was supported by King Saud University, Deanship of Scientific Research, College of Science and Research Centre.

The authors declare no conflicts of interest.

\section{References}

1. Hench LL (1991): Bioceramics: from concept to clinic. J Am Ceram Soc 74: 1487-1510.

2. LeGeros RZ, LeGeros JP: Dense hydroxyapatite. In: An introduction to bioceramics. Hench LL, Wilson J (eds.). Singapore, World Scientific. 1993; 139-180.

3. Gross UM, Muller-Mai C, Voigt C: Ceravital bioactive ceramics. In: An introduction to bioceramics. Hench LL, Wilson J (eds.). Singapore, World Scientific. 1993; 105-124.

4. Kokubo T, Shigematsu M, Nagashima Y, et al. (1982): Apatite and wollastonite-containing glass-ceramics for prosthetic application. Bull Inst Chem Res Kyoto Univ 60: 260-268.

5. Kokubo T: A/W glass-ceramics: processing and properties. In: An introduction to bioceramics. Hench LL, Wilson J (eds.). Singapore, World Scientific. 1993; 75-88.

6. Kokubo T (1991): Bioactive glass ceramics: properties and applications. Biomaterials 12: 155-163.

7. Kokubo T, Ito S, Huang ZT, et al. (1990): Ca, P-rich layer formed on high-strength bioactive glass-ceramic A-W. J Biomed Mater Res 24: 331-343.

8. Kokubo T, Kushitani H, Sakka S, et al. (1990): Solutions able to reproduce in vivo surface-structure changes in bioactive glass-ceramic A-W. J Biomed Mater Res 24: 721-734.

9. Cho SB, Nakanishi K, Kokubo T, et al. (1995): Dependence of apatite formation on silica gel on its structure: effect of heat treatment. J Am Ceram Soc 78: 1769-1774.

10. Kokubo T, Takadama H (2006): How useful is SBF in predicting in vivo bone bioactivity? Biomaterials 27: 2907-2915.

11. Ohtsuki C, Kamitakahara M, Miyazaki T (2009): Bioactive ceramic-based materials with designed reactivity for bone tissue regeneration. J R Soc Interface 6: S349-S360.

12. Zhang YH, Reller A (2003): Investigation of mesoporous and microporous nanocrystalline silicon doped titania. Materials Letters 57: 4108-4113.

13. Jiang XC, Herricks T, Xia YN (2003): One-dimensional nanostructures: synthesis, characterization and applications. Adv Mater 15: 1205-1209
14. Haugen H, Will J, Kohler A, et al. (2004): Ceramic $\mathrm{TiO}_{2}-$ foams: characterization of a potential scaffold. J Eur Ceram Soc 24: 661-668.

15. Meretoja VV, Tirri T, Aaritalo V, et al. (2007): Titania and titania-silica coatings for titanium: comparison of ectopic bone formation within cell-seeded scaffolds. Tissue Eng 13: 855-863.

16. Wu JM, Liu JF, Hayakawa S, et al. (2007): Low-temperature deposition of rutile film on biomaterials substrates and its ability to induce apatite deposition in vitro. J Mater Sci Mater Med 18: 1529-1536.

17. Hong SS, Lee MS, Park SS, et al. (2003): Synthesis of nanosized $\mathrm{TiO} / \mathrm{SiO}_{2}$ particles in the microemulsion and their photocatalytic activity on the decomposition of p-nitrophenol. Catal Today 87: 99-105.

18. Soo WL, Morillo C, Lira-Olivares J, et al. (2003): Tribological and microstructural analysis of $\mathrm{Al} 2 \mathrm{O} 3 / \mathrm{TiO}_{2}$ nanocomposites to use in the femoral head of hip replacement. Wear 255: 1040-1044.

19. Li J, Hastings GW: In: Handbook of Biomaterial Properties. Black J, Hastings GW (eds.). Chapman and Hall, London, New York. 1998; 340.

20. Burger W, Richter HG, Piconi C, et al. (1997): New Y-TZP powders for medical grade zirconia. J Mater Sci Mater Med 8: 113-118.

21. Liang H, Huang Y, He F, et al. (2007): Enhanced calcium phosphate precipitation on the surface of Mg-Ion-implanted $\mathrm{ZrO}_{2}$ bioceramic. Surf Rev Lett 14: 71-77.

22. Cales B (2000): Zirconia as a sliding material. Clin Orthop Relat Res 379: 94-112.

23. Clarke IC, Manaka M, Green DD, et al. (2003): Current status of zirconia used in total hip implants. J Bone Joint Surg Am 85: 73-84.

24. Kosmac T, Oblak C, Jevnikar P, et al. (2000): Strength and reliability of surface treated Y-TZP dental ceramics. J Biomed Mater Res 53: 304-313.

25. Benzaid R, Chevalier J, Malika Saadaoui M, et al. (2008): Fracture toughness, strength and slow crack growth in a ceria stabilized zirconia-alumina nanocomposite for medical applications. Biomaterials 29: 3636-3641.

26. Uchida M, Kim HM, Kokubo T, et al. (2002): Apatite forming ability of a Zirconia/ Alumina nano composite induced by chemical treatment. J Biomed Mater Res 60: 277-282.

27. Sharif MA, Sueyoshi H (2008): Microstructure and Properties of Wet Mixed Pyrolyzed ZrO2/Si/Phenol Resin Composite. Synth React Inorg Met Org Chem 38: 194-200.

28. Yan YY, Lu C (2009): Ultraviolet enhanced bioactivity of zirconia films prepared by micro-arc oxidation. Thin Solid Films 517: 1577-1581.

29. Ohtsuki C, Iida H, Nakamura S, et al. (1997): Bioactivity of titanium treated with hydrogen peroxide solutions containing metal chlorides. J Biomed Mater Res 35: 39-47.

30. Velmurugan R, Kanagesan S, Jesurani S, et al. (2010): Surface Bioactivity of Sol Gel Derived 3Y-TZP Bioinert Ceramic through Hydroxylation Technique using $5 \mathrm{M} \mathrm{NaOH}$. Eur J Sci Res 41: 430-436.

31. Najda J, Goss M, Gmiński J, et al. (1994): The antioxidant enzymes activity in the conditions of systemic hypersilicemia. Biol Trace Elem Res 42: 63-70.

32. Asahida T, Kobayashi T, Saitoh K, et al. (1996): Nakayama I. Tissue preservation and total DNA extraction from fish stored at ambient temperature using buffers containing high concentration of urea. Fish Sci 62: 727-730. 
33. Ueda T, Hayashi M, Koide N, et al. (1992): A preliminary study of the micronucleus test by acridine orange fluorescent staining compared with chromosomal aberration test using fish erythropoietic and embryonic cells. Water Sci Technol 25: 235-240.

34. Fairbairn DW, Olive PL, O’Neill KL (1995): Comet assay: A comprehensive review. Mutat Res 339: 37-59.

35. Collins A, Dusinska M, Franklin (1997): Comet assay in human biomonitoring studies: Reliability, validation, and applications. Environ Mol Mutagen 30: 139-146.

36. El-Megeed GA, Khalil WKB, Abdel Raouf A, et al. (2008): Synthesis and in vivo anti-mutagenic activity of novel melatonin derivatives. Eur J Med Chem 43: 763-770.

37. Zárybnická L, Vávrová J, Havelek R, et al. (2013): Lymphocyte subsets and their H2AX phosphorylation in response to in vivo irradiation in rats. Int J Radiat Biol 89: 110-117.

38. Rasmy GE, Khalil WKB, Moharib SA, et al. (2011): Dietary fish oil modulates the effect of dimethylhydrazine-induced colon cancer in rats. Grasas y Aceites 62: 253-267.

39. SAS (1982): SAS user's guide: statistics, edn. SAS Institute Inc., Cary, NC.

40. Karlsson KH (2004): Bioactivity of glass and bioactive glasses for bone repair. Glass Technology 45: 157-161.

41. Ebisawa Y, Kokubo T, Ohura K, et al. (1990): Bioactivity of $\mathrm{CaO} \bullet \mathrm{SiO} 2$-based glasses: in vitro evaluation. J Mater Sci: Mater Med 1: 239-244.

42. Beherei HH, Mohamed KR, El-Bassyouni GT (2009): Fabrication and characterization of bioactive glass (45S5)/titania Biocomposites. Ceramics International 35: 1991-1997.

43. Gerhardt LC, Jell GMR, Boccaccini AR (2007): Titanium dioxide $\left(\mathrm{TiO}_{2}\right)$ nanoparticles filled poly (D,L lactid acid) (PDLLA) matrix composites for bone tissue engineering. J Mater Sci: Mater Med 18:1287-1298.

44. Canesi L, Ciacci C, Betti M, et al. (2008): Immunotoxicity of carbon black nanoparticles to blue mussel hemocytes. Environ Int 34: 1114.

45. Schrand AM, Rahman MF, Hussain SM, et al. (2010): Metal-based nanoparticles and their toxicity assessment. Wiley Interdiscip Rev Nanomed Nanobiotechnol 2(5): 544-68.

46. Heckmann LH, Hovgaard MB, Sutherland DS, et al. (2011): Limit-test toxicity screening of selected inorganic nanoparticles to the earthworm Eisenia fetida. Ecotoxicology 20: 226233.

47. Adams LK, Lyon DY, Alvarez PJJ (2006): Comparative eco-toxicity of nanoscale $\mathrm{TiO}_{2}, \mathrm{SiO}_{2}$, and $\mathrm{ZnO}$ water suspensions. Water Res 40: 3527-3532.

48. Lovern SB, Klaper R (2006): Daphnia magna mortality when exposed to titanium dioxide and fullerene (C-60) nanoparticles. Environ Toxicol Chem 25:1132-1137.

49. Lindberg HK, Falck GCM, Catalán J, et al. (2012): Genotoxicity of inhaled nanosized $\mathrm{TiO}_{2}$ in mice. Mutat Res 745 : $58-64$.

50. Sadiq R, Bhalli JA, Yan J, et al. (2012): Genotoxicity of $\mathrm{TiO}_{2}$ anatase nanoparticles in $\mathrm{B} 6 \mathrm{C} 3 \mathrm{~F} 1$ male mice evaluated using Pig-a and flow cytometric micronucleus assays. Mutat Res 745: 65-72.

51. Warheit DB, Webb TR, Sayes CM, et al. (2006): Pulmonary instillation studies with nanoscale $\mathrm{TiO}_{2}$ rods and dots in rats: toxicity is not dependent upon particle size and surface area. Toxicol Sci 91: 227-236.

52. Grassian VH, O'shaughnessy PT, Adamcakova- Dodd A, et al. (2007): Inhalation exposure study of titanium dioxide nanoparticles with a primary particle size of 2 to $5 \mathrm{~nm}$. Environ Health Perspect 115: 397-402.

53. Sayes CM, Wahi R, Kurian PA, et al. (2006): Correlating nanoscale titania structure with toxicity: a cytotoxicity and inflammatory response study with human dermal fibroblasts and human lung epithelial cells. Toxicol Sci 92: 174-185.

54. Gurr JR, Wang AS, Chen CH, et al. (2005): Ultrafine titanium dioxide particles in the absence of photoactivation can induce oxidative damage to human bronchial epithelial cells. Toxicology 213: 66-73.

55. Long TC, Saleh N, Tilton RD, et al. (2006): Titanium dioxide (P25) produces reactive oxygen species in immortalized brain microglia (BV2): implications for nanoparticle neurotoxicity. Environ Sci Technol 40: 4346-4352.

56. Braydich-Stolle LK, Schaeublin NM, Murdock RC, et al. (2009): Crystal structure mediates mode of cell death in $\mathrm{TiO}_{2}$ nanotoxicity. J Nanopart Res 11: 1361-1374.

57. Feig DI, Reid TM, Loeb LA (1994): Reactive oxygen species in tumorigenesis. Cancer Res 54: 1890s-1894s.

58. Trouiller B, Reliene R, Westbrook A, et al. (2009): Titanium dioxide nanoparticles induce DNA damage and genetic instability in vivo in mice. Cancer Res 69: 8784-8789.

59. Burdon RH (1995): Superoxide and hydrogen peroxide in relation to mammalian cell proliferation. Free Radic Biol Med 18: 775-794.

60. Duan Y, Liu J, Ma L, et al (2010): Toxicological characteristics of nanoparticulate anatase titanium dioxide in mice. Biomaterials 31: 894-899.

61. Li N, Duan Y, Hong M, et al. (2010): Spleen injury and apoptotic pathway in mice caused by titanium dioxide nanoparticules. Toxicol Lett 195: 161-168.

62. Eydner M, Schaudien D, Creutzenberg O, et al. (2012): Impacts after inhalation of nano- and fine-sized titanium dioxide particles: Morphological changes, translocation within the rat lung, and evaluation of particle deposition using the relative deposition index. Inhal Toxicol 24: 557-569. 